\title{
TRANSIENT AND DIFFERENTIAL EXPRESSION OF ASPECTS OF THE CATECHOLAMINERGIC PHENOTYPE DURING DEVELOPMENT OF THE FETAL BOWEL OF RATS AND MICE ${ }^{1}$
}

\author{
M. D. GERSHON ${ }^{2}$ T. P. ROTHMAN, T. H. JOH, AND G. N. TEITELMAN \\ Department of Anatomy and Cell Biology, Columbia University, College of Physicians and Surgeons, New York, New York 10032 \\ and Laboratory of Neurobiology, Department of Neurology, Cornell University Medical College, New York, New York 10021
}

Received August 12, 1983; Revised December 12, 1983; Accepted March 9, 1984

\begin{abstract}
A population of proliferating cells in the fetal gut has previously been found to express transiently aspects of a catecholaminergic phenotype (TC cells) during development in both rats and mice. These cells appear to be noradrenergic in rats but dopaminergic in mice. In the current study, the ability of TC cells, identified by the immunocytochemical demonstration of tyrosine hydroxylase (TH), to take up and become radioautographically labeled by $\left[{ }^{3} \mathrm{H}\right]$ norepinephrine $\left(\left[{ }^{3} \mathrm{H}\right] \mathrm{NE}\right)$ was assessed. When TC cells were most numerous in the bowel of rats, no cells were labeled by $\left.{ }^{3} \mathrm{H}\right] \mathrm{NE}$ (days $\mathrm{E} 12$ and $\mathrm{E} 13$ ). In rats, but not mice, labeling of larger cell bodies by $\left[{ }^{3} \mathrm{H}\right] \mathrm{NE}$ was found on days E14 and E15. However, no cells showed TH immunoreactivity on day E15, although a few cells were doubly labeled by $\left[{ }^{3} \mathrm{H}\right] \mathrm{NE}$ and $\mathrm{TH}$ immunoreactivity on day E14. Therefore, in rats TC cells contain TH immunoreactivity but do not take up $\left[{ }^{3} \mathrm{H}\right] \mathrm{NE}$ prior to day E14, and their disappearance is followed by the appearance of a second population of larger cells that lacks TH immunoreactivity but which does take up $\left[{ }^{3} \mathrm{H}\right] \mathrm{NE}$. The transient appearance of some cells that express both markers on day E14 suggests, but does not prove, that TC cells change their phenotype and are the precursors of the cells found later in development that lack TH but which take up $\left[{ }^{3} \mathrm{H}\right] \mathrm{NE}$. The cells that take up $\left[{ }^{3} \mathrm{H}\right] \mathrm{NE}$ are rare or absent in newborn rat gut, indicating that they may also be transient. These results indicate that genes responsible for different aspects of the noradrenergic phenotype need not necessarily be coupled in their expression. Although uptake of $\left[{ }^{3} \mathrm{H}\right]$ $\mathrm{NE}$ into cell bodies was not found on day E13 or later in vivo in mouse gut, it does occur in mouse bowel explanted prior to day E13 and grown for 10 to 12 days in culture. These cultures also contained TH immunoreactive cells. Thus, the potential for development of cells able to take up $\left[{ }^{3} \mathrm{H}\right] \mathrm{NE}$ exists in mice as well as in rats, and the conditions that lead to a loss of catecholaminergic traits in vivo do not exist in vitro.
\end{abstract}

In adult animals, the catecholaminergic cells of the sympathetic nervous system and brain can be defined by their stable content of specific biosynthetic enzymes and a high affinity catecholamine uptake mechanism, as well as by their content of catecholamines (Geffen and Jarrott, 1977). The biosynthetic enzymes, tyrosine hydroxylase (TH) and dopamine $\beta$-hydroxylase $(\mathrm{DBH})$, are limited in their distribution to neurons, SIF (small intensely fluorescent) cells, and chromaffin tissue. During development, however, catecholaminergic cells appear in locations that, in adult animals, do not contain catecholaminergic neurons, SIF cells, or chromaffin tissue (Cochard et al., 1978; Jonakait et al., 1982; Teitelman et al., 1978, 1981b). These cells, defined as those able to synthesize and store catecholamines and which do not persist into adult life, have

\footnotetext{
${ }^{1}$ This work was supported by National Institutes of Health Grants NS15547 and HL-18974, National Science Foundation Grants BNS7911640 and 82-04904, March of Dimes Grant 1-747, and the Dysautonomia Foundation. We wish to thank Ms. Linda Toga and Mrs. Helen Mantulin for excellent technical assistance and Ms. Diane Sherman for excellent electron micrographs.

${ }^{2}$ To whom correspondence should be addressed.
}

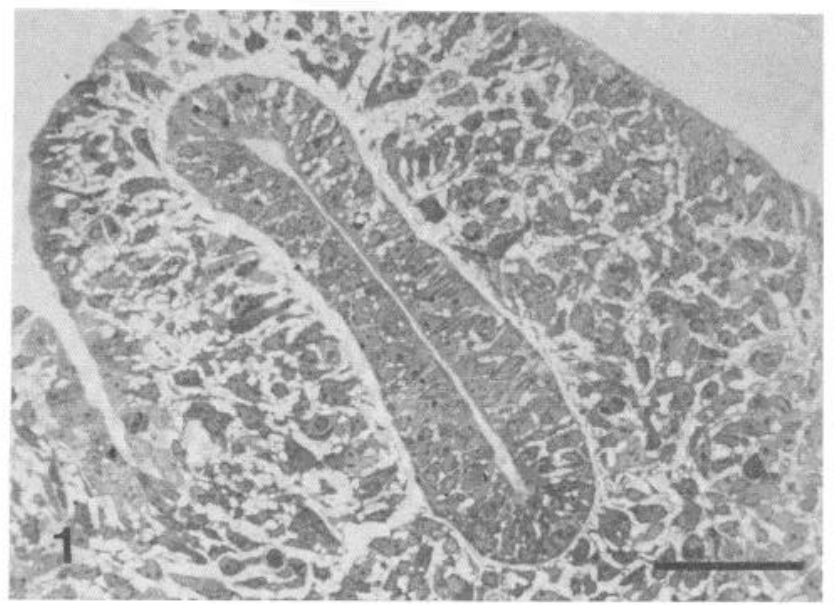

Figure 1. Fetal rat gut at day E12. The tissue was incubated with $\left[{ }^{3} \mathrm{H}\right] \mathrm{NE}$ and processed for radioautography. A $1-\mu \mathrm{m}$ thick epoxy section stained with toluidine blue is illustrated. No structures are labeled. No neuronal elements can morphologically be discerned in the enteric mesenchyme. The marker $=50 \mu \mathrm{m}$. 

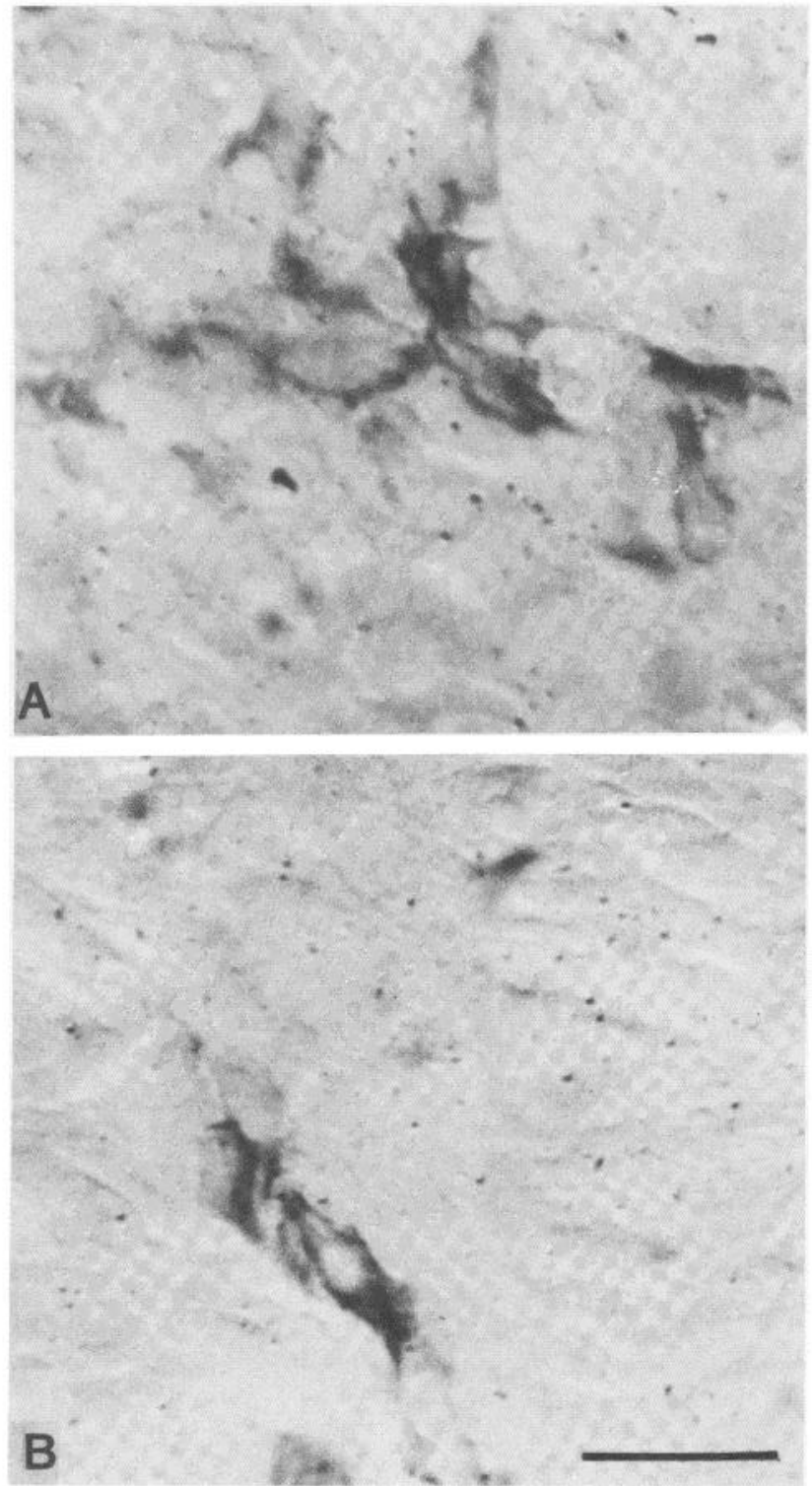

Figure 2. Fetal rat gut at day E12. The tissue was incubated with $\left[{ }^{3} \mathrm{H}\right] \mathrm{NE}$ and processed to demonstrate simultaneously TH by immunocytochemistry and $\left[{ }^{3} \mathrm{H}\right] \mathrm{NE}$ by radioautography. Two areas are shown illustrating cells in the enteric mesenchyme that contain $\mathrm{TH}$ immunoreactivity. The cells do not radioautographically label with $\left[{ }^{3} \mathrm{H}\right] \mathrm{NE}$. The marker $=20 \mu \mathrm{m}$.

been called transient catecholaminergic (TC) cells. TC cells were first reported in the fetal rat gut where they abound, but similar cells are also natural constituents of other fetal organs of rats and mice (Teitelman et al., 1979). The TC cells, in rats, contain both TH and DBH but not phenylethanolamine $N$ methyltransferase, and, thus, the catecholamine revealed in them by histofluorescence is probably stored norepinephrine (NE). However, the comparable cells of mice do not contain $\mathrm{DBH}$ and, therefore, probably are dopaminergic (Teitelman et al., 1981a). In both rats (Teitelman et al., 1981a) and mice (G. Teitelman, T. Rothman, and M. D. Gershon, unpublished results) the TC cell population is a proliferating one.

In the adult rat and mouse gut, there are no intrinsic catecholaminergic cells (Furness and Costa, 1980; Gershon, 1981). All of the enteric catecholamine, as well as the biosynthetic enzymes, TH and $\mathrm{DBH}$, is accounted for by the extrinsic sympathetic innervation derived from neuronal cell bodies in the prevertebral ganglia (Furness and Costa, 1974, 1978). However, it has been reported (Furness and Costa, 1978) that there is a population of intrinsic enteric neurons that contain aromatic L-amino acid decarboxylase and will synthesize either dopamine or 5-hydroxytryptamine from the exogenously administered precursors, L-dihydroxy-phenylalanine or L-5-hydroxytryptophan, respectively. These cells have been called "amine-handling cells." One additional property of amine-handling cells is an ability to take up catecholamine (Furness et al., 1980). The relationship of amine-handling cells to TC cells is uncertain. It has been reported that cells that take up catecholamine are found in the gut after the disappearance of TC cells, marked by TH or endogenous catecholamine histofluorescence (Jonakait et al., 1979). This uptake has been interpreted as the persistence of one characteristic (the amine uptake mechanism) of TC cells after others are lost; however, the ability of TC cells themselves to take up NE has not previously been demonstrated. Therefore, it is possible that the cells that take up catecholamine in the gut after TC cells have disappeared are a new population, perhaps the "amine-handling cells" of the adult bowel, and may be unrelated to the TC cells.

The current experiments were done to determine whether some or all TC cells take up NE. In addition, the timing of the acquisition of the amine uptake mechanism was analyzed to determine whether various aspects of the catecholaminergic phenotype, such as acquisition of TH and amine uptake, might be uncoupled. Finally, the timing of the loss of ability of TC cells to synthesize NE was correlated with the ingrowth of the noradrenergic postganglionic sympathetic nerves into the gut. $\mathrm{TH}$ immunocytochemistry was used as a TC cell marker and $\left[{ }^{3} \mathrm{H}\right] \mathrm{NE}$ radioautography was used as a probe for ability of cells or fibers to take up catecholamines. Experiments were done comparatively in both rats and mice. A preliminary report of some of these observations has appeared (Gershon et al., 1982).

\section{Materials and Methods}

Studies were done with CD-1 mice, originally obtained from Charles River, and bred at Columbia. Dated pregnant Sprague-Dawley rats

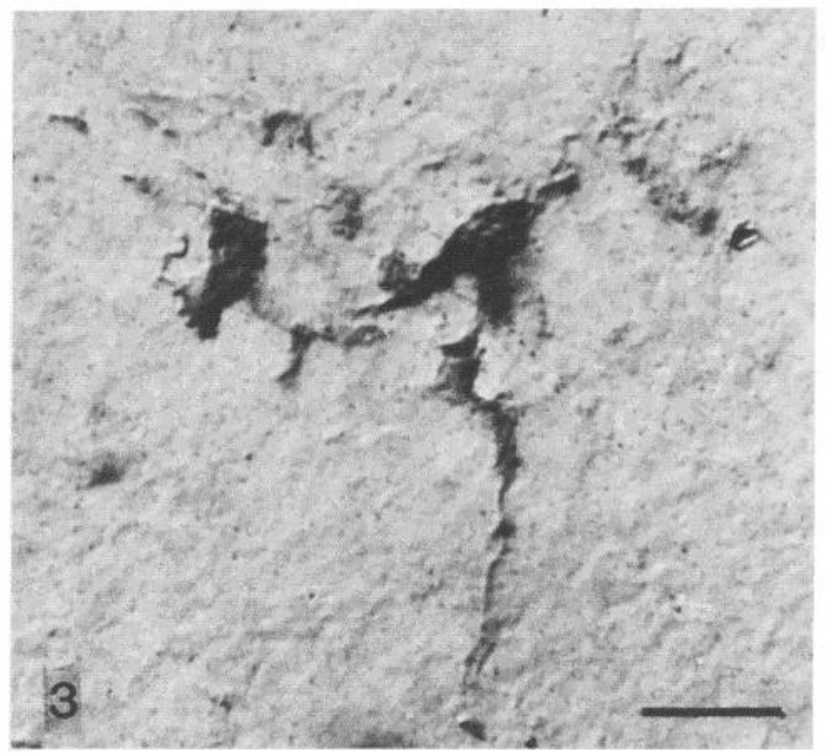

Figure 3. Fetal rat gut at day E13. The tissue was incubated with $\left[{ }^{3} \mathrm{H}\right] \mathrm{NE}$ and processed to demonstrate simultaneously $\mathrm{TH}$ by immunocytochemistry and $\left[{ }^{3} \mathrm{H}\right] \mathrm{NE}$ by radioautography. TC cells are illustrated that contain TH immunoreactivity; however, the cells are not labeled by $\left[{ }^{3} \mathrm{H}\right] \mathrm{NE}$. Compare this figure with Figure 2 . The marker $=$ $30 \mu \mathrm{m}$. 


\section{TABLE I}

Quantitative analysis of rat catecholaminergic cell size and number between days E12 and E14

Three hundred sixty-two cells and the outlines of the intestinal sections that contained them were traced using a Leitz Bioquant RII program on an Apple II plus computer and a Bausch and Lomb Hi Pad digitizing tablet. The cellular and intestinal profiles were traced directly employing a camera lucida attachment to a microscope equipped with Nomarski differential contrast interference optics. Areas are expressed in square micrometers and perimeters in micrometers. The areas of TH- or $\left[{ }^{3} \mathrm{H}\right] \mathrm{NE}$-marked cells in a given section of gut were summed and divided by the total area of that section to get the percentage of intestinal area, while the number of such cells was divided by the area of the section of gut containing them to derive the number of cells per square micrometer of gut. Between days E12 and E13, TC cells increase in perimeter, percentage of intestinal area, and number of cells per square micrometer of gut. By day E14, these parameters decrease to approximately the E12 values for all cells showing a catecholaminergic property, TH immunoreacivity, $\left[{ }^{3} \mathrm{H}\right] \mathrm{NE}$ uptake, or both. At day E14, cells that take up $\left[{ }^{3} \mathrm{H}\right] \mathrm{NE}$ but do not display TH immunoreactivity are more numerous and constitute a greater percentage of intestinal area than either cells with TH alone or doubly labeled cells. Cells at this age that take up $\left[{ }^{3} \mathrm{H}\right] \mathrm{NE}$ are also significantly larger in their cross-sectional area than those that do not. Because of the high resolution of radioautography due to the weak energy and short path length traveled by the $\beta$ particles of ${ }^{3} \mathrm{H}$, it is unlikely that size measurements are significantly increased in the raioautographs. Coincidence of outline between labeled cells and their overlying radioautographic image was noted. Because of the ingrowth of sympathetic fibers at day E15, a quantitative analysis of catecholaminergic cells was not done at this age.

\begin{tabular}{|c|c|c|c|c|c|c|}
\hline Age & $\begin{array}{l}\text { No. of Cells } \\
\text { Examined }\end{array}$ & Area/Cell & Perimeter/Cell & $\begin{array}{c}\text { Marked Cells } \\
\text { Percentage of } \\
\text { Intestinal Area }\end{array}$ & $\begin{array}{l}\text { No. of Marked Cells/ } \\
\mu \mathrm{m}^{2} \text { of Gut } \\
\left(\times 10^{-5}\right)\end{array}$ & $\begin{array}{l}\text { Percentage of All Cells } \\
\text { Marked by TH and/or } \\
{\left[{ }^{3} \mathrm{H}\right] \mathrm{NE} \text { at This Age }}\end{array}$ \\
\hline & & $\mu m^{2}$ & $\mu m$ & & & \\
\hline E12 & 75 & $144 \pm 14$ & $96 \pm 6$ & $0.41 \pm 0.02$ & $3.17 \pm 0.37$ & \\
\hline E13 & 57 & $136 \pm 12$ & $210 \pm 15^{a}$ & $1.14 \pm 0.29^{b}$ & $5.99 \pm 0.99^{c}$ & \\
\hline $\begin{array}{l}\text { E14 (all cells marked by } \\
\text { TH and/or }\left[{ }^{3} \mathrm{H}\right] \mathrm{NE} \text { ) }\end{array}$ & 230 & $182 \pm 12^{d}$ & $104 \pm 7^{e}$ & $0.53 \pm 0.08^{f}$ & $4.35 \pm 0.96$ & \\
\hline \multicolumn{7}{|l|}{ Day E14 subsets } \\
\hline TH only & 41 & $(126 \pm 11)$ & $(121 \pm 18)$ & $(0.11 \pm 0.03)$ & $(0.69 \pm 0.15)$ & 18 \\
\hline$\left[{ }^{3} \mathrm{H}\right] \mathrm{NE}$ only & 145 & $(195 \pm 12)^{g}$ & $(98 \pm 5)$ & $(0.58 \pm 0.10)^{h}$ & $(2.73 \pm 0.78)^{i}$ & 63 \\
\hline Doubly labeled & 44 & $(189 \pm 13)^{j}$ & $(110 \pm 7)$ & $(0.20 \pm 0.04)^{k}$ & $(0.93 \pm 0.17)^{l}$ & 19 \\
\hline
\end{tabular}

${ }^{a} \mathrm{E} 13$ versus $\mathrm{E} 12, p<0.001$.

${ }^{b} \mathrm{E} 12$ versus $\mathrm{E} 13, p<0.01$.

${ }^{c} \mathrm{E} 13$ versus $\mathrm{E} 12, p<0.01$.

${ }^{d}$ E13 versus E14 (all TH and/or [ $\left.{ }^{3} \mathrm{H}\right] \mathrm{NE}$ cells), $p<0.01$.

${ }^{e} \mathrm{E} 14$ (all TH and/or $\left[{ }^{3} \mathrm{H}\right] \mathrm{NE}$ cells) versus $\mathrm{E} 13, p<0.001$.

${ }^{f} \mathrm{E} 14$ (all TH and/or $\left[{ }^{3} \mathrm{H}\right] \mathrm{NE}$ cells) versus $\mathrm{E} 13, p<0.05$.

${ }^{g} \mathrm{TH}$ only versus $\left[{ }^{3} \mathrm{H}\right] \mathrm{NE}$ only at $\mathrm{E} 14, p<0.001$.

${ }^{h} \mathrm{TH}$ only versus $\left[{ }^{3} \mathrm{H} \mid \mathrm{NE}\right.$ only at $\mathrm{E} 14, p<0.002$.

${ }^{i} \mathrm{TH}$ only versus $\left[{ }^{3} \mathrm{H}\right] \mathrm{NE}$ only at $\mathrm{E} 14, p<0.05$.

${ }^{j}$ Doubly labeled versus TH only at E14, $p<0.001$.

${ }^{k}$ Doubly labeled versus $\left[{ }^{3} \mathrm{H}\right] \mathrm{NE}$ only at E14, $p<0.01$.

'Doubly labeled versus $\left[{ }^{3} \mathrm{H}\right] \mathrm{NE}$ only at E14, $p<0.05$.

were obtained from Hilltop Lab Animals (Scotsdale, PA). The date of conception, for both rats and mice, was established by the presence of a vaginal plug and was designated as day 1 of gestation (E1) in rats and day 0 (E0) in mice.

Immunocytochemistry. Antiserum was prepared against TH that had been purified from rat adrenal gland. The procedure for preparation of the antiserum as well as the criteria used to judge its specificity have already been described (Joh et al., 1973). The antiserum is monospecific and is the same antiserum as used previously to detect TC cells in rats and mice (Teitelman et al., 1981a).

For immunocytochemistry tissues were fixed in a solution containing $4 \%$ formaldehyde (from paraformaldehyde), buffered to $\mathrm{pH} 7.4$ with $0.1 \mathrm{M}$ sodium phosphate buffer. The fixed tissues were infilirated with $30 \%$ sucrose overnight for cryoprotection and cut the following day in a cryostat microtome (Hacker-Bright). TH immunoreactivity was demonstrated as described in earlier studies (Teitelman et al., 1979, 1981a). Controls consisted of incubation of sections with pre-immune serum and showed no reaction product.

Radioautography. Segments of fetal gut were incubated in $5 \mathrm{ml}$ of Krebs solution at $37^{\circ} \mathrm{C}$, bubbled continuously with $95 \% \mathrm{O}_{2}$ and $5 \%$ $\mathrm{CO}_{2}$, containing the monoamine oxidase inhibitor, pargyline $(0.1 \mathrm{mM}$; Rothman et al., 1976). After a 15 -min equilibration period, $\left[{ }^{3} \mathrm{H}\right] \mathrm{NE}(0.5$ $\mu \mathrm{M}$; specific activity $13.4 \mathrm{Ci} / \mathrm{mmol}$; New England Nuclear Corp.) was added, and the incubation was allowed to continue for an additional 30 min. Following incubation, the fetal gut was transferred to iced fixative $(2 \mathrm{hr})$. For radioautography alone, a mixture containing $0.5 \%$ acrolein, $2 \%$ glutaraldehyde, $2 \%$ formaldehyde (from paraformaldehyde), and $0.5 \%$ dimethylsulfoxide in $0.1 \mathrm{M}$ sodium cacodylate buffer with $0.01 \%$
$\mathrm{CaCl}_{2}$ and $3 \%$ sucrose was employed. When simultaneous radioautography and immunocytochemistry was to be done, the formaldehydecontaining fixative described above for immunocytochemistry was used instead. The fixation time in this case was $4 \mathrm{hr}$. The triple aldehydefixed material was postfixed in $1 \% \mathrm{OsO}_{4}$ containing $3 \%$ sucrose, rapidly dehydrated through a graded series of ethanols, cleared in propylene oxide, and embedded in epoxy resin (Epon 812). The formaldehydefixed tissue was infiltrated in $30 \%$ sucrose, cryostat sectioned, and processed for the immunocytochemical demonstration of $\mathrm{TH}$, as described above.

For light microscopic radioautography, Epon sections were cut at 1.0 $\mu \mathrm{m}$ and placed on slides that were coated with chromium alum gelatin. Slides containing frozen sections that had been treated for the immunocytochemical demonstration of $\mathrm{TH}$ were washed in $0.1 \mathrm{M}$ sodium phosphate buffer ( $\mathrm{pH}$ 7.4) and processed immediately thereafter for radioautography without being permitted to dry. Ilford $L 4$ photographic emulsion was diluted $1: 1$ with distilled $\mathrm{H}_{2} \mathrm{O}$ and applied to the slides by dipping. Slides were exposed for 14 to 28 days in lighttight boxes containing a drying agent (Drierite) at $4^{\circ} \mathrm{C}$. Electron microscopic radioautography (Kopriwa, 1975) was done by placing ultrathin sections onten collodion-coated glass slides covered with carbon and layered with Ilford L4 emulsion, as described previously (Rothman and Gershon, 1982).

Tissues that had been incubated with $\left[{ }^{3} \mathrm{H}\right] \mathrm{NE}$ in the presence of desmethylimipramine $(0.01 \mu \mathrm{M})$ or at $4^{\circ} \mathrm{C}$ in parallel with experimental tissues served as controls for all radioautographic procedures. No radioautographic labeling was observed in these tissues. This indicated that radioautographic labeling reflected the activity of the specific NE 

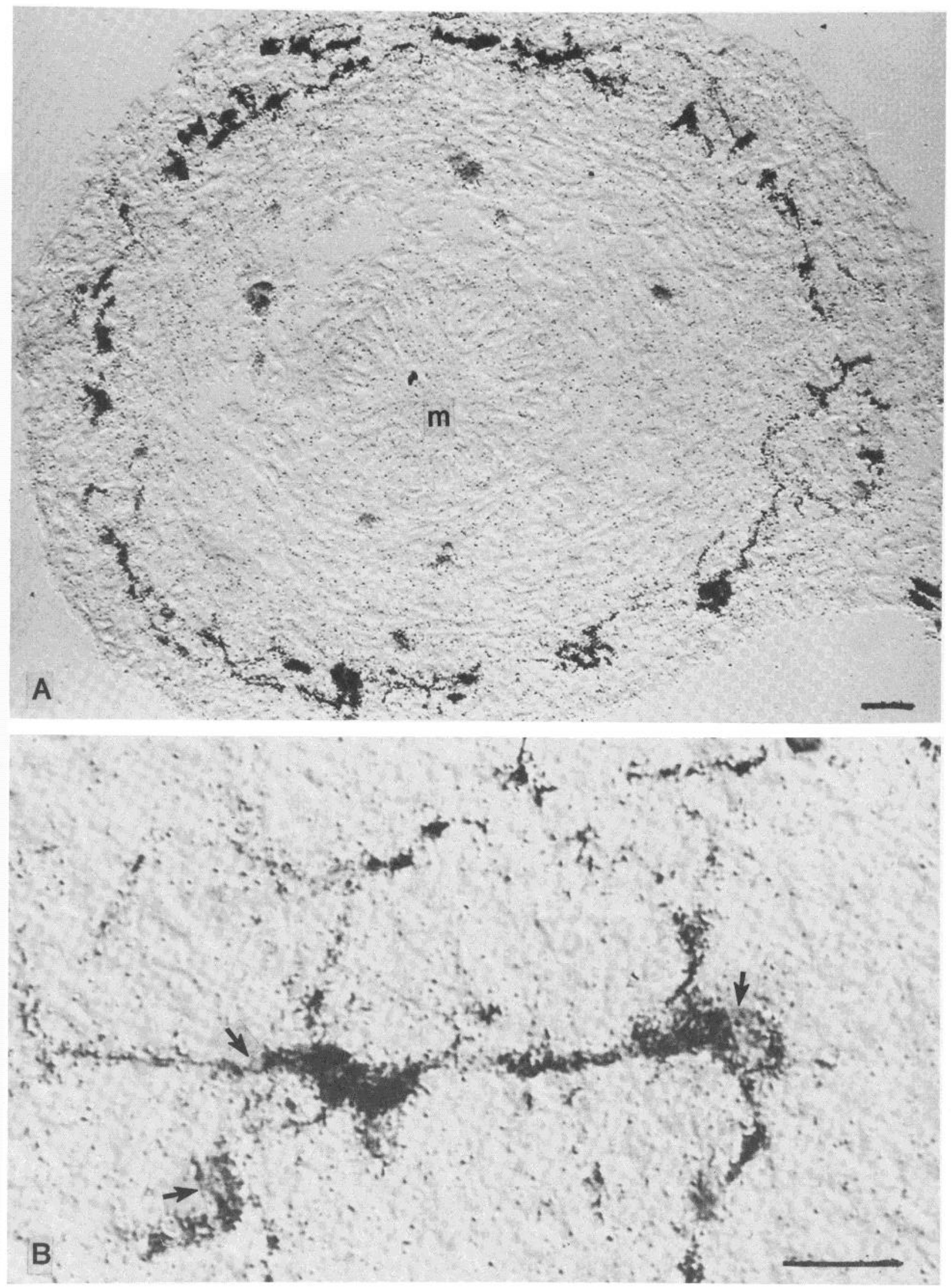

Figure 4. Fetal rat gut at day E15. The tissues was processed to demonstrate TH immunoreactivity and [ $\left.{ }^{3} \mathrm{H}\right] \mathrm{NE}$ identically as for the tissue illustrated in Figures 2 and 3 . At low magnification $(A)$ an extensive neuritic network radioautographically labeled by [ $\left.{ }^{3} \mathrm{H}\right] \mathrm{NE}$ can be seen in the region of the myenteric plexus, which has by now developed. $m$, mucosa. At higher magnification $(B)$, the radioautographic silver grains (black) can be seen to overlie fibers that contain TH immunoreactivity (gray; arrows). No cell bodies are found at this age that contain TH. The markers $=20 \mu \mathrm{m}$. 


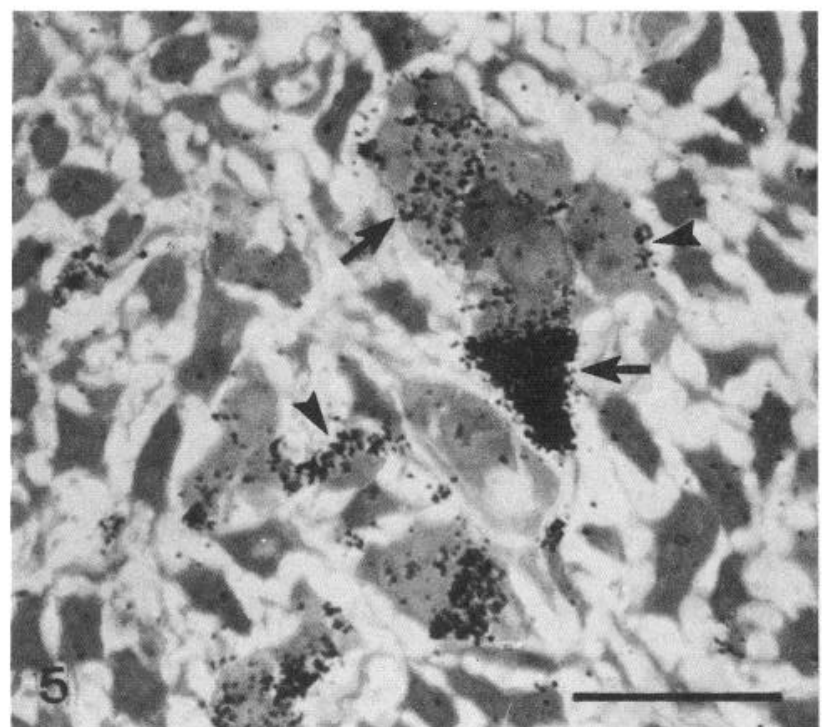

Figure 5. Fetal rat gut at day E15. The tissue was incubated with $\left[{ }^{3} \mathrm{H}\right] \mathrm{NE}$ and processed for radioautography. A $1-\mu \mathrm{m}$ thick epoxy section, stained with toluidine blue, is illustrated. Both cell bodies (arrows) and fibers coursing through the enteric mesenchyme or abutting on unlabeled neurons (arrowheads) are labeled. The marker $=20 \mu \mathrm{m}$.

uptake mechanism. Since no radioautographic labeling was found in tissues that contained the DAB reaction product when uptake of $\left[{ }^{3} \mathrm{H}\right]$ $\mathrm{NE}$ was inhibited, or prior to the age when this uptake developed, it can be concluded that the immunocytochemical reaction product does not artifactually produce a labeling pattern by chemography. Similar results have been obtained in an earlier study that combined radioautography and immunocytochemistry using the peroxidase-antiperoxidase technique and DAB (Rothman et al., 1980). Since doubly labeled cells were found in some tissues and radioautographic results were not different depending on whether immunocytochemistry was or was not done (see "Results"), it can be concluded that the combined technique does not interfere with the radioautographic demonstration of $\left[{ }^{3} \mathrm{H}\right] \mathrm{NE}$.

Tissue culture. Fetal mouse gut was removed at days E11 and E12 and grown as organotypic tissue cultures for 10 to 12 days in Maximow slide assemblies as lying drop preparations (Rothman and Gershon, 1982). For radioautography with $\left[{ }^{3} \mathrm{H}\right] \mathrm{NE}$ the cultures were first washed for 15 min with Hanks' solution containing pargyline $(0.1 \mathrm{mM})$. Incubation with $\left[{ }^{3} \mathrm{H}\right] \mathrm{NE}(0.5 \mu \mathrm{M})$ was done in regular growth medium to which pargyline $(0.1 \mathrm{~mm})$ was added. Incubation was followed by a brief dip in iced Hanks' solution containing $3 \%$ sucrose and finally by fixation in $3 \%$ gluraldehyde, containing $3 \%$ sucrose, in $0.1 \mathrm{M}$ sodium phosphate buffer (pH 7.4) for $1.5 \mathrm{hr}$ at $4^{\circ} \mathrm{C}$. The cultures were postfixed with $\mathrm{OsO}_{4}$, embedded in Epon 812, and further processed for radioautography as described above. For immunocytochemistry, cultures were infiltrated with $30 \%$ sucrose and processed as described above for fetal tissues.

\section{Results}

TH-positive, $\left[{ }^{3} \mathrm{H}\right] \mathrm{NE}$-negative cells. At day E12 of development the primitive foregut of the fetal rat consists of an epithelial-lined mucosa surrounded by a relatively thick mesenchyme, enclosed within a thin layer of serosal squamous epithelial cells (Fig. 1). No elements of the enteric nervous system are morphologically evident. At this time, however, TC cells are well developed and can be demonstrated immunocytochemically with antisera to TH (Fig. 2 and Table I). When the fetal rat gut at day E12 is incubated with $\left[{ }^{3} \mathrm{H}\right] \mathrm{NE}$ and processed for radioautography, no cells or processes are labeled (Fig. 1). Simultaneous TH immunocytochemistry and $\left[{ }^{3} \mathrm{H}\right] \mathrm{NE}$ radioautography reveal TC cells containing $\mathrm{TH}$ immunoreactivity, but these cells are not labeled by $\left[{ }^{3} \mathrm{H}\right] \mathrm{NE}$.

On day E13 TC cells demonstrable by TH immunocytochemistry are still present in the fetal rat gut (Fig. 3 and Table I). The individual TC cells appear more highly branched than they were on day E12, and some exhibit long thin processes. As a result of this change in shape, the TC cells show an increase in their perimeter without an accompanying increase in crosssectional area (Table I). TC cells also are more numerous in the bowel on day E13 than on day E12 both as a percentage of total intestinal area and as the number of cells encountered per unit intestinal area (Table I). However, fetal rat tissue incubated with $\left[{ }^{3} \mathrm{H}\right] \mathrm{NE}$ and prepared for simultaneous $\mathrm{TH}$ immunocytochemistry and $\left[{ }^{3} \mathrm{H}\right] \mathrm{NE}$ radioautography continues to reveal only the immunoreactivity of $\mathrm{TH}$ in TC cells. On day E13 as on day E12, therefore, no uptake of $\left[{ }^{3} \mathrm{H}\right] \mathrm{NE}$ by TC cells can be demonstrated.

$\left[{ }^{3} H\right] N E$-positive, TH-negative cells. On day E15, as reported previously (Cochard et al., 1978; Teitelman et al., 1978), no cells were found in the fetal rat gut that contain $\mathrm{TH}$ immunoreactivity. However, TH immunoreactivity was seen in neuritic processes (Fig. 4). These processes avidly take up $\left[{ }^{3} \mathrm{H}\right] \mathrm{NE}$ and radioautographically label. Double labeling of processes by $\mathrm{TH}$ immunocytochemistry and $\left[{ }^{3} \mathrm{H}\right] \mathrm{NE}$ radioautography was evident. In contrast to TH immunoreactivity which was not found in cell bodies, $\left[{ }^{3} \mathrm{H}\right] \mathrm{NE}$ radioautographically labeled cells as well as processes (Fig. 5)

Electron microscopic radioautography was done on material incubated with $\left[{ }^{3} \mathrm{H}\right] \mathrm{NE}$ to verify the identification of labeled elements and to examine their ultrastructure. The processes that were labeled appeared to be both preterminal axons (Fig. 6 and 7) and growth cones (Fig. 7). The developing enteric nervous system at day E15 is still quite primitive, and $\left[{ }^{3} \mathrm{H}\right] \mathrm{NE}$ labeled neurites were found in close proximity to dividing neuroblasts. Cells that label with $\left[{ }^{3} \mathrm{H}\right] \mathrm{NE}$ also appeared to be primitive (Fig. 8). They contain many free ribosomes, relatively little rough endoplasmic reticulum, and the Golgi apparatus is inconspicuous. The labeled cells are often located close to neurites, but, aside from their specific labeling by $\left[{ }^{3} \mathrm{H}\right] \mathrm{NE}$, the cells do not have a neuronal appearance. On day E15, therefore, the fetal gut contains cells that display $\left[{ }^{3} \mathrm{H}\right] \mathrm{NE}$ uptake but not $\mathrm{TH}$ immunoreactivity and many neuritic processes that show both properties. The abundance of the processes and the presence of labeled growth cones suggest that they represent the invasion of the bowel by the extrinsic sympathetic innervation.

$T H$-positive, $\left[{ }^{3} \mathrm{H}\right] N E$-positive cells. Thus, the course of development of the fetal rat gut is marked first by cells that contain TH but do not label with $\left[{ }^{3} \mathrm{H}\right] \mathrm{NE}$ and then by cells that label with $\left[{ }^{3} \mathrm{H}\right] \mathrm{NE}$ but do not have $\mathrm{TH}$. The second cell population could arise de novo or be derived from the cells that originally contain TH. If the cells that take up $\left[{ }^{3} \mathrm{H}\right] \mathrm{NE}$ are derived from the cells that contain $\mathrm{TH}$, it might be expected that the change from one phenotype to another would be reflected by at least some transitional cells that display both properties. Thus, transitional cells were sought in the fetal rat gut on day E14.

Fetal gut from rats on day E14 was incubated with $\left[{ }^{3} \mathrm{H}\right] \mathrm{NE}$ and prepared for simultaneous $\mathrm{TH}$ immunocytochemistry and $\left[{ }^{3} \mathrm{H}\right] \mathrm{NE}$ radioautography. On day E14, less of the bowel was occupied by catecholamingergic cells than on day E13 (as a percentage of total intestinal area; Table I), but some cells with TH immunoreactivity are still present. Cells that take up $\left[{ }^{3} \mathrm{H}\right]$ $\mathrm{NE}$ are also present (Fig. $9 \mathrm{~A}$ ) and, in fact, are more abundant in the E14 fetal rat gut than are cells with TH immunoreactivity (Fig. $9 B$ and Table I). Thus, the bowel at this age contains many cells that express the $\left[{ }^{3} \mathrm{H}\right] \mathrm{NE}$ uptake property but which are not shown with TH antisera (Fig. $9, A$ and $B$ ). Some doubly labeled cells, that are shown both by TH immunocytochemistry and by $\left[{ }^{3} \mathrm{H}\right] \mathrm{NE}$ radioautography, are present (Fig. $9, A$ and $B$ ). These doubly labeled cells are not uncommon, but they are less numerous than cells that are labeled by $\left[{ }^{3} \mathrm{H}\right] \mathrm{NE}$ alone. The doubly labeled cells are about as numerous as the residual cells that display TH at this age but which do not take up $\left[{ }^{3} \mathrm{H}\right] \mathrm{NE}$. At day E14, therefore, the catecholaminergic cell population 


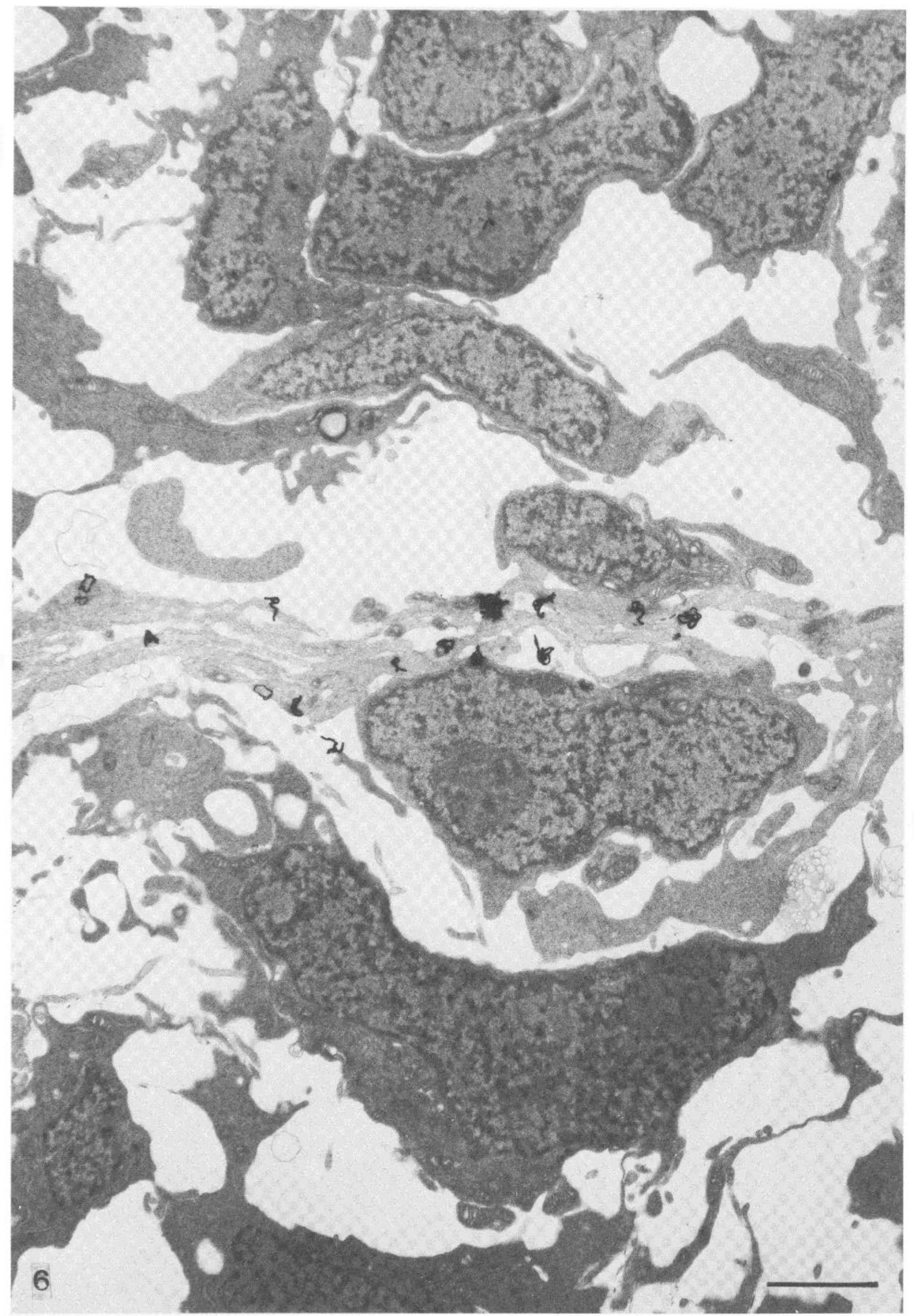

Figure 6. Fetal rat gut at day E15. The tissue was incubated with $\left[{ }^{3} \mathrm{H}\right] \mathrm{NE}$ and processed for electron microscopic radioautography. A bundle of neurites coursing through the enteric mesenchyme has taken up $\left[{ }^{3} \mathrm{H}\right] \mathrm{NE}$ and become selectively labeled. The neurites have the appearance of primitive preterminal axons and lack the varicosities that characterize mature noradrenergic terminals (for detail see Fig. 7 ). The marker $=$ $2 \mu \mathrm{m}$. 

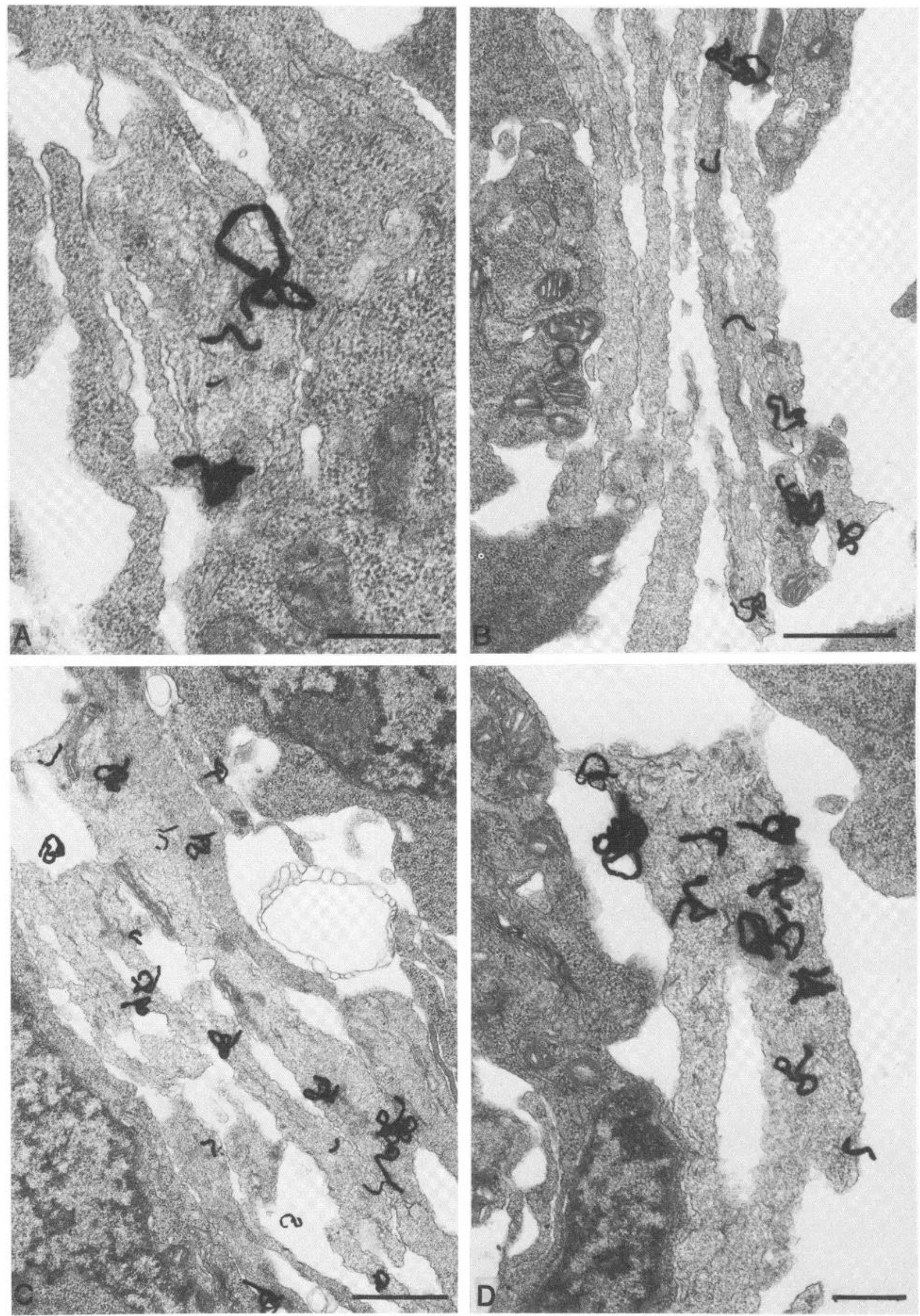

Figure 7. Fetal rat gut at day E15. Electron microscopic radioautographic demonstration of $\left[{ }^{3} \mathrm{H}\right] \mathrm{NE}$ as in Figure 6. Axonal swellings which contain smooth membrane elements and filaments and are probably growth cones $(A$ and $D)$, as well as preterminal axons $(B$ and $C)$, are labeled. Some of the axonal swellings contain large granulated vesicles $(A)$, but the mass of 50 -nm small vesicles that characterize mature noradrenergic terminal varicosities is not yet apparent. The markers $=0.5 \mu \mathrm{m}(A$ and $D)$ and $1.0 \mu \mathrm{m}(B$ and $C)$. 


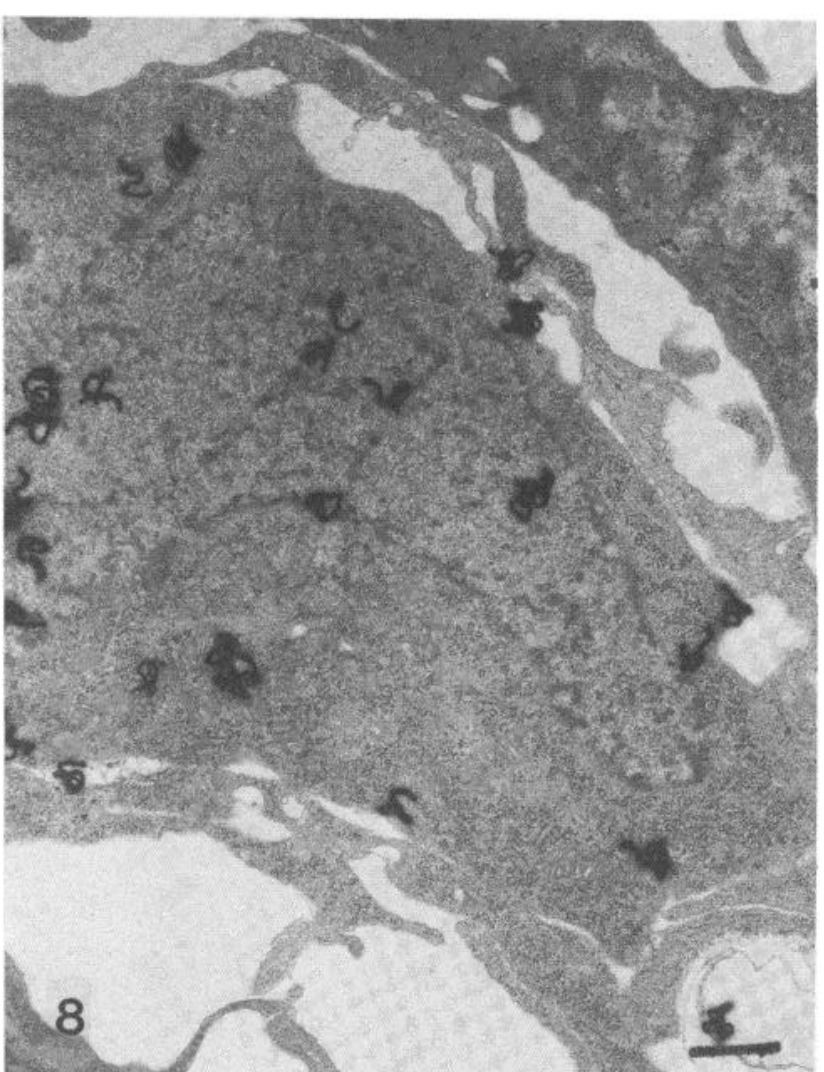

Figure 8. Fetal rat gut at day E15. Electron microscopic radioautographic demonstration of $\left[{ }^{3} \mathrm{H}\right] \mathrm{NE}$ as in Figures 6 to 8 . A labeled cell body is shown in the primitive myenteric plexus. Note the abundance of free ribosomes and the paucity of profiles of rough endoplasmic reticulum in the cytoplasm. Thus, the cell does not have the Nissl bodies that characterize mature neurons. Label has penetrated into the nucleus as has previously been described for $\left[{ }^{3} \mathrm{H}\right] \mathrm{NE}$ in the mature brain (Descarries and Droz, 1970). The marker $=1.0 \mu \mathrm{m}$.

consists of three types of cells, a cell that contains TH but does not take up $\left[{ }^{3} \mathrm{H}\right] \mathrm{NE}$, a cell that takes up $\left[{ }^{3} \mathrm{H}\right] \mathrm{NE}$ but which does not express $\mathrm{TH}$ immunoreactivity, and a cell that expresses both properties. The cells that take up $\left[{ }^{3} \mathrm{H}\right] \mathrm{NE}$, with or without the TH marker, are significantly larger in cross-sectional area than the cells that express $\mathrm{TH}$ immunoreactivity alone.

At the time of birth, labeling of the bowel by $\left[{ }^{3} \mathrm{H}\right] \mathrm{NE}$ is intense (Fig. 10). The dense pattern of labeling is at least primarily, and possibly entirely, in neuritic processes in both myenteric and submucosal plexuses. Clear examples of labeled cell bodies were not found. At this time, therefore, the cell bodies labeled with $\left[{ }^{3} \mathrm{H}\right] \mathrm{NE}$ have either disappeared or become rare and difficult to find.

Uptake of $\left[{ }^{3} \mathrm{H}\right] \mathrm{NE}$ in the fetal mouse gut. Fetal mouse stomach, duodenum, ileum, and colon were incubated with $\left[{ }^{3} \mathrm{H}\right] \mathrm{NE}$ and processed for radioautography. TC cells have been found in the murine bowel beginning on day E10, and they disappear prior to E13 (Teitelman et al., 1981a). No specific uptake of $\left[{ }^{3} \mathrm{H}\right] \mathrm{NE}$ was detected on day E13 in the murine gut. Beginning in the stomach on day E14, neuritic labeling was observed. Labeled cell bodies were not found from days E13 and E15 in any segment of fetal gut (Fig. 11).

To determine whether the fetal mouse gut prior to day E13 contains precursors of cells that can acquire the ability to take up $\left[{ }^{3} \mathrm{H}\right] \mathrm{NE}$, explants of fetal mouse bowel were removed and grown in organotypic tissue culture for 10 to 12 days. This technique provides an assay for precursor cells because no cells from elsewhere in the embryo can migrate into the gut grown as an explant in vitro; therefore, any cell type that appears in the culture has to be derived from a cell that was present in the original explant. After 12 days' growth in organotypic tissue culture, $\left[{ }^{3} \mathrm{H}\right] \mathrm{NE}$ was added to the cultures and the explants were processed for radioautography. Both cells and apparent terminals that take up $\left[{ }^{3} \mathrm{H}\right] \mathrm{NE}$ were found to have developed in the cultures (Fig. 12B). These cultures also contained cells that displayed $\mathrm{TH}$ immunoreactivity (Fig. 12A). On day E12,
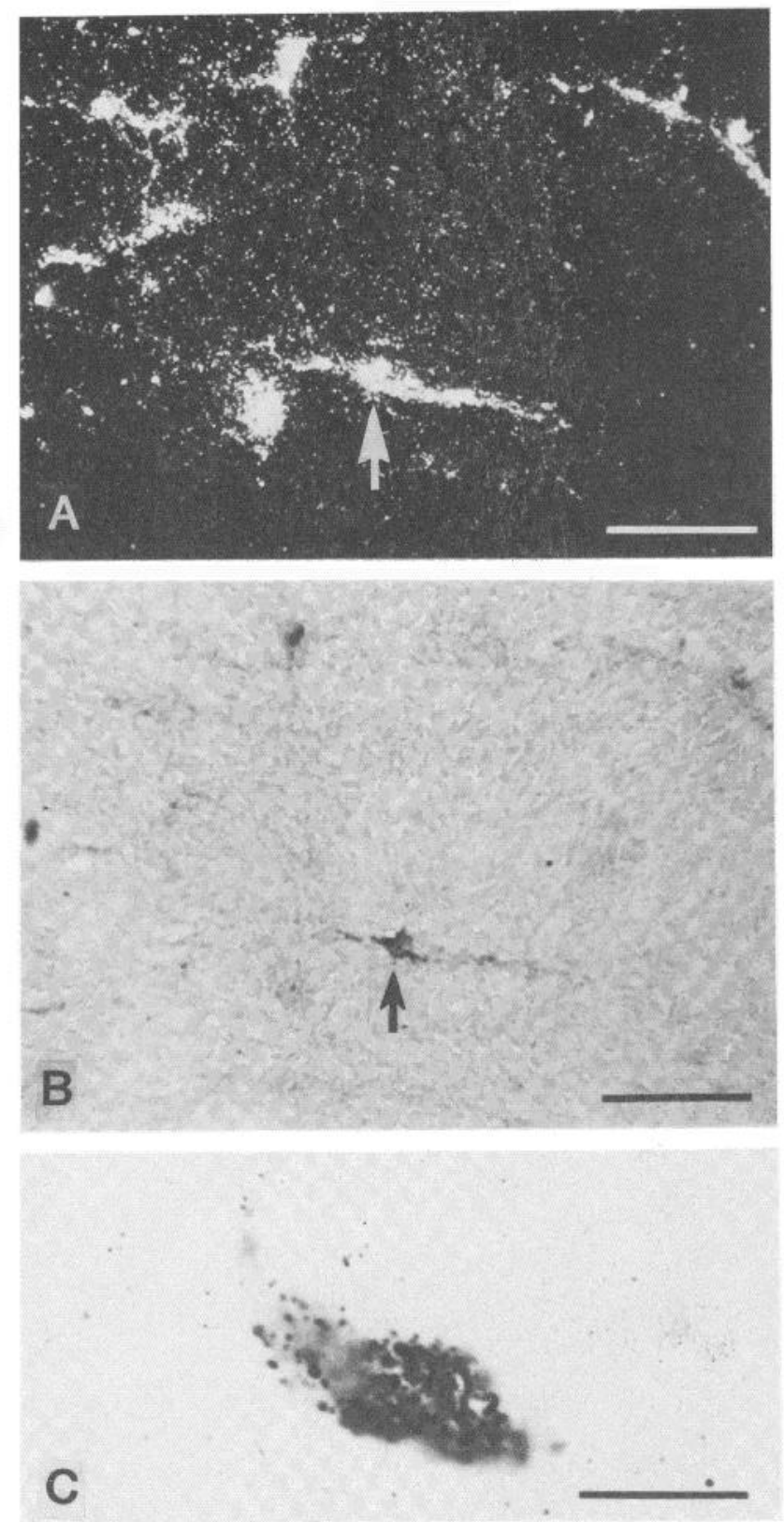

Figure 9. Fetal rat gut at day E14. The tissue was incubated with $\left[{ }^{3} \mathrm{H}\right] \mathrm{NE}$ and processed to demonstrate simultaneously $\mathrm{TH}$ by immunocytochemistry and $\left[{ }^{3} \mathrm{H}\right] \mathrm{NE}$ by radioautography as in Figures 2 to 4 . $A$, Darkfield microscopy focused on the overlying photgraphic emulsion showing $\left[{ }^{3} \mathrm{H}\right] \mathrm{NE}$-labeled cells and their processes. $B$, Brightfield microscopy of the same field shown in $A$, but focused on the plane of the tissue. One of the $\left[{ }^{3} \mathrm{H}\right] \mathrm{NE}$-labeled cells (arrows) contains both $\left[{ }^{3} \mathrm{H}\right] \mathrm{NE}$ and TH immunoreactivity. $C$, High magnification of a doubly labeled cell taken with brightfield optics. The markers $=50 \mu \mathrm{m}(A$ and $B)$ and $10 \mu \mathrm{m}(C)$. 

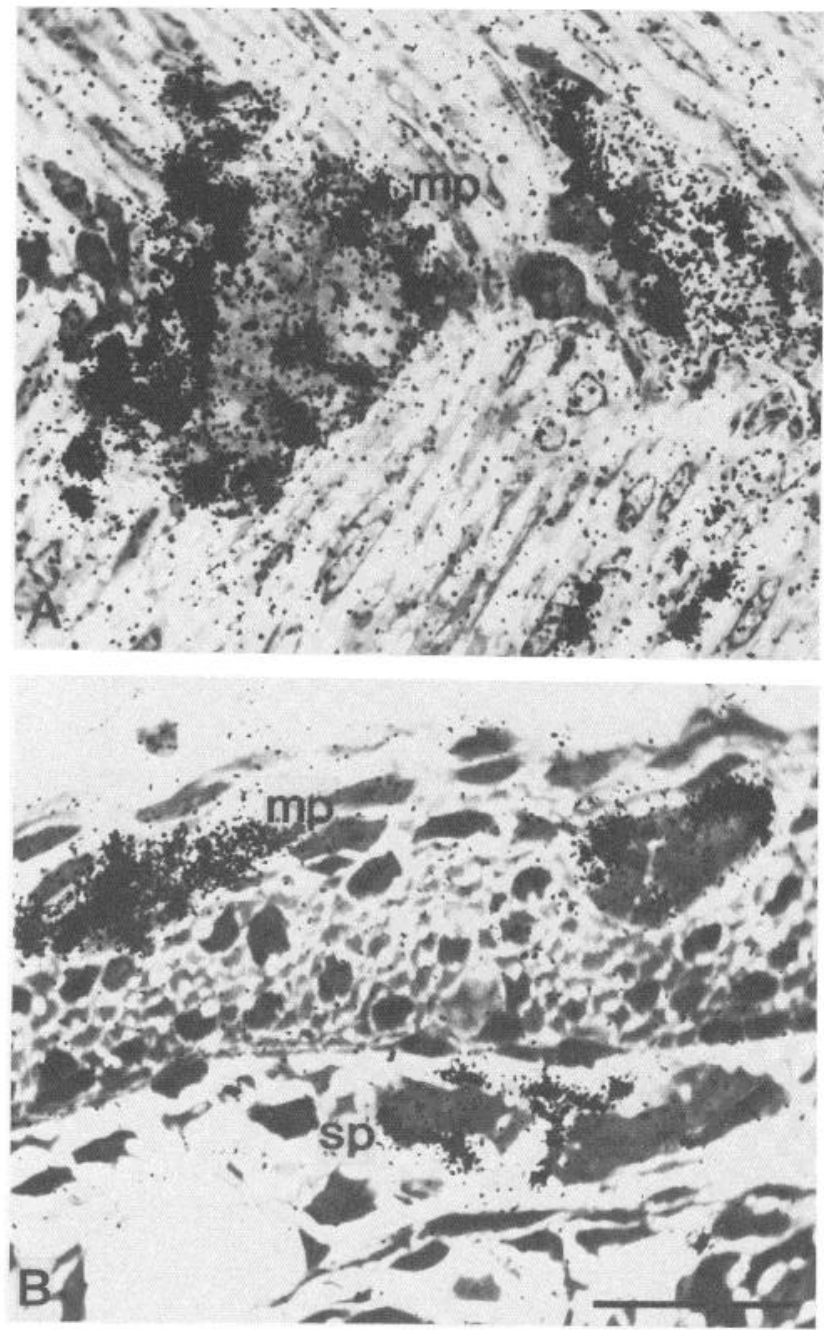

Figure 10. Newborn rat gut. The tissue was incubated with $\left[{ }^{3} \mathrm{H}\right] \mathrm{NE}$ and processed for radioautography as in Figures 1 and 5. One-micrometer thick epoxy sections, stained with toluidine blue, are illustrated. $A$, The dense labeling of the myenteric neuropil shows a characteristic tendency toward a peripheral distribution around myenteric ganglia (Manber and Gershon, 1979), but clearly labeled cell bodies are not seen. $B$, Intense labeling by $\left[{ }^{3} \mathrm{H}\right] \mathrm{NE}$ is seen in the neuropil of the myenteric plexus $(m p)$. The submucosal plexus $(s p)$ now contains fibers labeled by $\left[{ }^{3} \mathrm{H}\right] \mathrm{NE}$ as well. The marker $=20 \mu \mathrm{m}$.

therefore, the fetal mouse gut contains the precursors of cells that acquire a NE uptake mechanism in vitro. In culture, moreover, the property of TH immunoreactivity does not disappear from the gut as it does in vivo.

\section{Discussion}

One goal of the current experiments was to determine whether some or all TC cells have an amine uptake mechanism. Previous analyses of this property have relied on histofluorescence (Jonakait et al., 1979). Fetal gut, in these earlier studies, was incubated with micromolar concentrations of $\mathrm{NE}$, and formaldehyde-induced fluorescence (FIF) was looked for in cells of the wall of the bowel. Since endogenous NE is present in cells of the gut until day E13.5 (Cochard et al., 1978) or E14 (Teitelman et al., 1981a), it is impossible using FIF to determine whether uptake of exogenous NE occurs in cells of the gut containing their own endogenous amine, or into another cell type. (Note that Cochard et al. (1978) consider the discovery of a plug day 0.5 of gestation, while Teitelman et al. (1981a) consider it day E1. As a result, Cochard's day E13.5 is equivalent to Teitelman's E14. The convention used in the current study is that of Teitelman et al. (1981a)). After TC cells with endogenous NE have disappeared, of course, the ability of incubation with exogenous NE to induce FIF in enteric cells does indicate that these cells take up the amine; therefore, FIF is a valid method of evaluating uptake of $\mathrm{NE}$ in the rat only after days E13.5 (Cochard et al., 1978) or E14 (Teitelman et al., 1981a) when endogenous $\mathrm{NE}$ has been lost. On the other hand, radioautography done on tissues incubated with $\left[{ }^{3} \mathrm{H}\right] \mathrm{NE}$ not only is not subject to interference by endogenous NE but also is an extremely sensitive technique for the detection of the amine uptake mechanism in developing neurites. For example, during the development of sympathetic noradrenergic neurons, uptake of NE can be seen prior to the appearance of endogenous NE detectable by FIF (Gershon and Thompson, 1973). Therefore, radioautography with $\left[{ }^{3} \mathrm{H}\right] \mathrm{NE}$ was used to explore the ability of the TC cell population to take up NE.

Fetal rat gut was incubated with $\left[{ }^{3} \mathrm{H}\right] \mathrm{NE}$ on days E12 and E13 when TC cells are at the height of their development. Radioautography was done both under conditions ideal for detection of labeling and under conditions that permitted the simultaneous visualization of $\mathrm{TH}$ by immunocytochemistry and labeling by $\left[{ }^{3} \mathrm{H}\right] \mathrm{NE}$. Both conditions were used so that uptake into any cells, if present, would not be missed. Neither technique revealed labeling of cells by $\left[{ }^{3} \mathrm{H}\right] \mathrm{NE}$ although TH immunocytochemistry showed that the fetal rat gut contained TC cells which increased in abundance and morphological complexity between days E12 and E13. Failure of the earliest TC cells to take up $\left[{ }^{3} \mathrm{H}\right] \mathrm{NE}$ has been confirmed by Jonakait et al. (1983). It is concluded that TC cells, when they are most numerous, do not take up radioautographically demonstrable $\mathrm{NE}$; therefore, the genes responsible for the various aspects of the noradrenergic phenotype, as represented in mature noradrenergic neurons (NE synthesis, storage, release (not studied), and reuptake), can be uncoupled, at least in these cells, in their expression.

By day E15, radioautography revealed that the gut contained many cells that labeled with $\left[{ }^{3} \mathrm{H}\right] \mathrm{NE}$, although cells shown by the immunocytochemical demonstration of $\mathrm{TH}$ had disappeared. Thus, this observation confirms the prior report, using FIF (Jonakait et al., 1979), of NE uptake into enteric cells at this age. However, the $\left[{ }^{3} \mathrm{H}\right] \mathrm{NE}$-labeled cells cannot be called TC cells because they do not synthesize NE, and radioautographic labeling by $\left[{ }^{3} \mathrm{H}\right] \mathrm{NE}$ is not a property of all TC cells. Thus, the late developing cells marked by labeling with $\left[{ }^{3} \mathrm{H}\right]$ $\mathrm{NE}$ are best thought of as a new cell population. However, this new population may be derived by differentiation from the original TC cells. If so, the appearance of the new population of cells labeled by $\left[{ }^{3} \mathrm{H}\right] \mathrm{NE}$ would be indicative of a developmentally regulated change in phenotype of precursor cells in the fetal gut.

To evaluate the possibility that cells labeled by $\left[{ }^{3} \mathrm{H}\right] \mathrm{NE}$ are derived from TC cells, transitional forms were carefully looked for on day E14 when TH-marked TC cells begin to disappear and $\left[{ }^{3} \mathrm{H}\right] \mathrm{NE}$-labeled cells first appear. It was anticipated that such transitional cells might be doubly labeled by TH immunoreactivity and $\left[{ }^{3} \mathrm{H}\right] \mathrm{NE}$ for a brief period of time if the TC cell is a precursor to the cell that takes up $\left[{ }^{3} \mathrm{H}\right] \mathrm{NE}$. TH biosynthesis may continue for a time after the new property of uptake of $\left[{ }^{3} \mathrm{H}\right] \mathrm{NE}$ is acquired. Alternatively, the new cells that have acquired the amine uptake property might have lost the ability to synthesize $\mathrm{TH}$ while still retaining enough $\mathrm{TH}$ that they synthesized previously to be immunocytochemically detectable for a short period of time. Although most (about 60\%) of the cells labeled by $\left[{ }^{3} \mathrm{H}\right] \mathrm{NE}$, even on day E14, showed that property alone and did not contain $\mathrm{TH}$ immunoreactivity, a small number of cells was definitely present that was doubly 

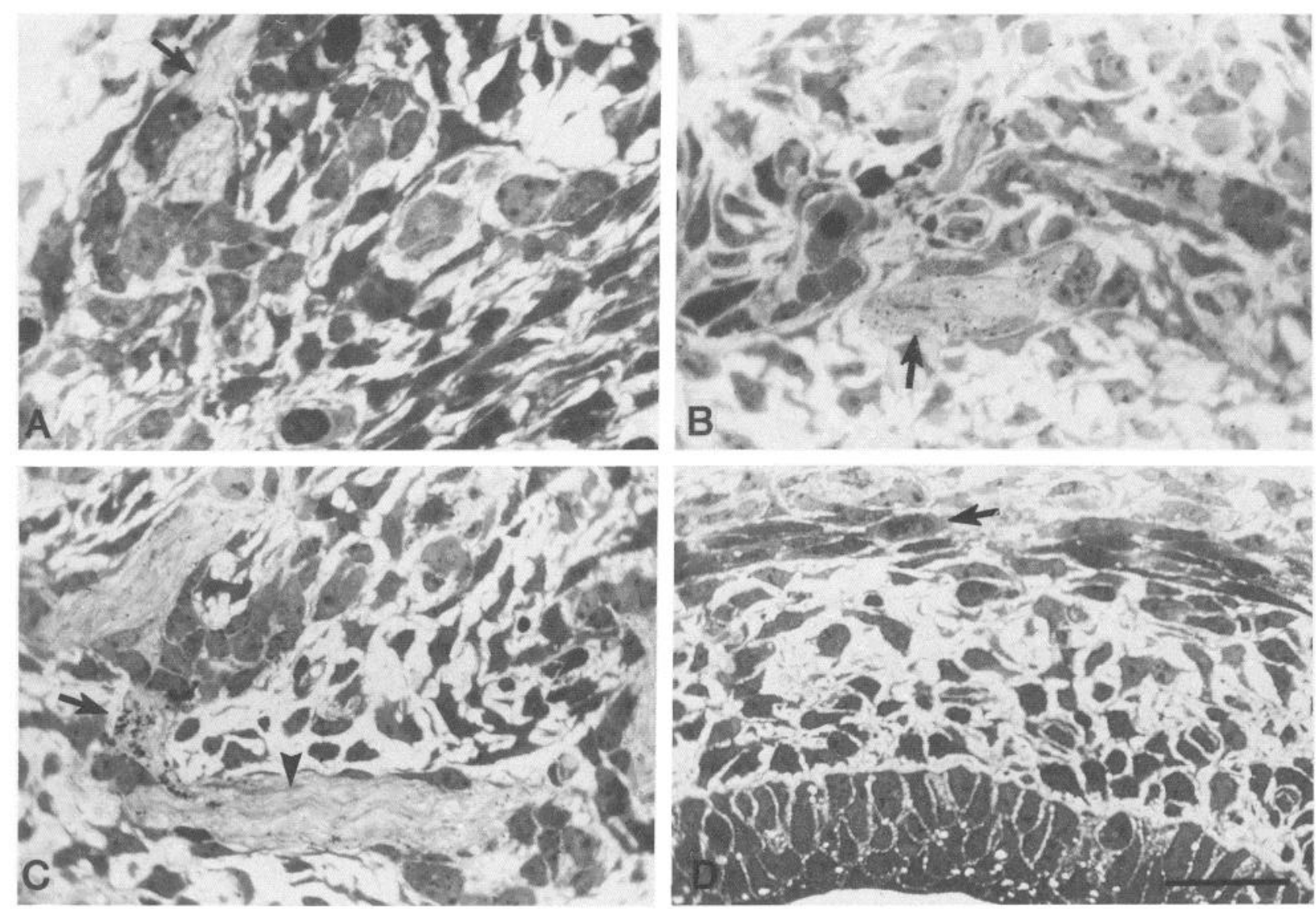

Figure 11. Fetal mouse gut (stomach) at days E13 $(A), \mathrm{E} 14(B)$, and E15 $(C$ and $D)$. The tissue was incubated with $\left[{ }^{3} \mathrm{H}\right] \mathrm{NE}$ and processed for radioautography. All photographs are of epoxy sections, cut at $1.0 \mu \mathrm{m}$ and stained with toluidine blue. On day E13 the fetal mouse stomach contains neuritic islands of primitive myenteric plexus within the enteric mesenchyme (arrow); however, neither the neuropil nor cell bodies are labeled. By day E14 $(B)$ the earliest sign of $\left[{ }^{3} \mathrm{H}\right] \mathrm{NE}$ uptake appears as light labeling of bundles of neurites in myenteric ganglia (arrow). By day E15 labeling of neuritic bundles is more commonly encountered and is more intense (arrow). Bundles of labeled neurities often appear to be approaching the myenteric plexus from the serosal surface of the gut. Most neuritic bundles even at day E15 (arrowhead) are not labeled. $D$, Labeling of the myenteric neuropil is abolished by desmethylimipramine. The primitive nature of the murine myenteric plexus at E15 is made apparent by the frequent occurrence of cells in mitosis (arrow) within myenteric ganglia. The markers $=20 \mu \mathrm{m}$.

labeled by both probes (about $20 \%$ of the cells labeled by $\left[{ }^{3} \mathrm{H}\right]$ $\mathrm{NE})$. This age is clearly one of transition because the catecholaminergic population at day E14 is composed of three subsets of cells, residual TC cells labeled by $\mathrm{TH}$ immunocytochemistry alone, cells labeled by $\left[{ }^{3} \mathrm{H}\right] \mathrm{NE}$ alone, and those labeled by both markers. The significantly larger cellular size (Table I) of the two subsets that take up $\left[{ }^{3} \mathrm{H}\right] \mathrm{NE}$ is evidence that the cells that take up $\left[{ }^{3} \mathrm{H}\right] \mathrm{NE}$ are not members of the same population of TC cells as those that do not take up the amine. Nevertheless, the observations are consistent with the hypothesis, initially posed, that TH-labeled TC cells are the precursors of at least some of the cells labeled by $\left[{ }^{3} \mathrm{H}\right] \mathrm{NE}$. However, it still remains conceivable, since relatively few cells are doubly labeled by $\mathrm{TH}$ immunocytochemistry and $\left[{ }^{3} \mathrm{H}\right] \mathrm{NE}$ radioautography, that the doubly labeled set is simply marking a rapidly eliminated cell type that synthesizes TH as well as takes up $\left[{ }^{3} \mathrm{H}\right] \mathrm{NE}$. TC cells, identified by $\mathrm{TH}$ immunocytochemistry, might then not be the precursors of the bulk of the new population of cells present after day E14 that labels with $\left[{ }^{3} \mathrm{H}\right] \mathrm{NE}$.

The cell that takes up $\left[{ }^{3} \mathrm{H}\right] \mathrm{NE}$ at E14 and E15 in the rat may give rise to the "amine-handling cells" of the adult bowel that have been described by others (Furness and Costa, 1978; Furness et al., 1980); however, no clear evidence was found in newborn rats of uptake of $\left[{ }^{3} \mathrm{H}\right] \mathrm{NE}$ into cell bodies, as opposed to extensive labeling of neuritic processes. At the light microscopic level it is possible that such cell bodies exist but are obscured by the dense overlay of sympathetic fibers. At the electron microscopic level, it might be difficult to find these cells if they are rare. Nevertheless, it is likely that the cells present after day E14 that label with $\left[{ }^{3} \mathrm{H}\right] \mathrm{NE}$ are themselves transient. They may be an additional precursor population that disappears because it changes its phenotype, or they may be lost through differential cell death.

The current study adds to the known species differences between the TC cell populations of rats and mice. The murine $\mathrm{TC}$ cells are similar to those of rats in that they appear and have largely disappeared prior to the development of a recognizable myenteric plexus (Teitelman et al., 1981a). However, the TC cells of mice are dopaminergic, not noradrenergic as in rats. In contrast to the fetal rat gut, moreover, the fetal mouse bowel was not found to acquire, on day E13 in vivo, a substantial cell population that takes up and labels with $\left[{ }^{3} \mathrm{H}\right] \mathrm{NE}$. Therefore, murine TC cells have not yet been demonstrated to be the precursors of another identified cell type. They may, in consequence, either change their phenotype and acquire characteristics as yet unknown, or they may be eliminated.

It is of interest that murine bowel explanted at a time when TC cells are present, days E11 or E12, does contain cells after 10 to 12 days' growth in organotypic tissue culture that display TH immunoreactivity and cells that take up $\left[{ }^{3} \mathrm{H}\right] \mathrm{NE}$ and become radioautographically labeled. This observation indicates that the potential for the development of cells able to take up 


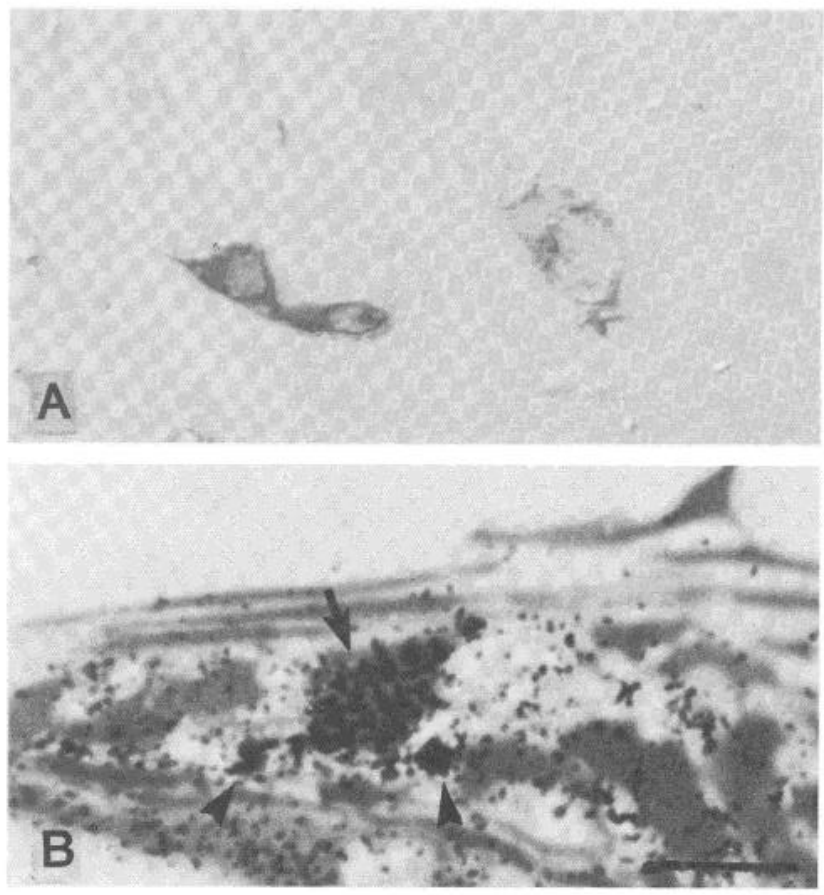

Figure 12. Organotypic tissue cultures of explants of mouse intestine. The fetal proximal small intestine was explanted on day E11 $(A)$ or day E12 $(B)$ and grown in culture for $10(A)$ or $12(B)$ days. The explants were then prepared for the immunohistochemical demonstration of TH $(A)$ or incubated with $\left[{ }^{3} \mathrm{H}\right] \mathrm{NE}$ and processed for radioautography $(B)$. A, Small cells in the cultures continue to display TH immunoreactivity. $B$, A $1.0-\mu \mathrm{m}$ thick epoxy section, through the explant, stained with toluidine blue, is illustrated. A labeled cell (arrow) can be seen in a small ganglion as well as some "hot spots" (arrowheads) indicative of labeled terminal varicosities (Rothman and Gershon, 1982). The markers $=10 \mu \mathrm{m}$.

$\left[{ }^{3} \mathrm{H}\right] \mathrm{NE}$ exists in mice as well as rats and that the TH-marked cell population does not disappear in vitro as it does in vivo. The precursors of cells found in culture to take up $\left[{ }^{3} \mathrm{H}\right] \mathrm{NE}$ or display $\mathrm{TH}$ immunoreactivity must have been present on days E11 and E12 when the explants were made. It is not yet clear why the radioautographic labeling of cells by $\left[{ }^{3} \mathrm{H}\right] \mathrm{NE}$ is not expressed on day E13 in vivo in the mouse. The trait persists in vivo in rats, as it does not in mice, even after TH immunoreactivity is lost. It is likely that a factor or factors present in vivo but lacking in the cultures, suppresses the expression of these catecholaminergic phenotypic characteristics. (The extrinsic nerves of the bowel could be such a factor.) It is possible that the TC cells which were included in the explants were the precursors of the cells that take up $\left[{ }^{3} \mathrm{H}\right] \mathrm{NE}$ in the cultures, but available data do not permit this conclusion to be drawn. Further experiments need to be done to determine if doubly labeled cells are ever present in mice.

The relationship of both the TC cell population and the cells that label with $\left[{ }^{3} \mathrm{H}\right] \mathrm{NE}$ to the ingrowth of the noradrenergic sympathetic innervation needs further investigation. The disappearance of TC cells and the appearance of cells that take up $\left[{ }^{3} \mathrm{H}\right] \mathrm{NE}$ are temporally correlated in the rat with the invasion of the gut by sympathetic nerves. This correlation could be coincidental. Alternatively, it is possible that the phenomena are causally related or that the TC cells and the cells that take up $\left[{ }^{3} \mathrm{H}\right] \mathrm{NE}$ subserve a necessary function ultimately taken over by the sympathetic nerves. In the mouse, however, the timing with respect to the sympathetic innervation and the disappearance of TC cells is different from that in the rat. The sympathetic nerves reach the murine stomach but not the small intestine on day E14. On the other hand, TC cells have disappeared from the entire mouse gut prior to day E13, and no cells are found on day E13 that take up $\left[{ }^{3} \mathrm{H}\right] \mathrm{NE}$, Thus, no correlation exists in mice between the timing of the ingrowth of sympathetic nerves and the disappearance of TC cells. The species difference between rats and mice argues against a causal relationship between the ingrowth of sympathetic nerves and the disappearance of TC cells.

In conclusion, the current experiments have provided evidence that noradrenergic phenotypic characteristics can be uncoupled in their expression during development. TC cells can synthesize NE but probably do not take up the amine. TC cells may be the precursors, through differentiation, of another transient cell population distinguished by radioautographic labeling with $\left[{ }^{3} \mathrm{H}\right] \mathrm{NE}$. The phenomena concerning the transient expression of catecholaminergic phenotypic characteristics are quite different in mice and rats. TC cells appear in both species; however, the TC cells are dopaminergic not noradrenergic in mice, while they are noradrenergic in rats. The population of cells that take up and become radioautographically labeled by $\left[{ }^{3} \mathrm{H}\right] \mathrm{NE}$ does not appear on day $\mathrm{E} 13$ in vivo in the murine bowel; however, the appearance of cells that display $\mathrm{TH}$ immunoreactivity as well as cells labeled by $\left[{ }^{3} \mathrm{H}\right] \mathrm{NE}$ in cultured murine gut indicates that mice as well as rats have the potential for the development of these cells and that factors that induce the disappearance of catecholaminergic properties in vivo are not present in vitro. Considerable insight into neuronal development may be derived from future experiments to determine the microenvironmental or other factors that regulate catecholaminergic expression by enteric neuroblasts during the course of development.

\section{References}

Cochard, P., M. Goldstein and I. B. Black (1978) Ontogenetic appearance and disappearance of tyrosine hydroxylase and catecholamines in the rat embryo. Proc. Natl. Acad. Sci. U. S. A. 75: 2986-2990.

Descarries, L., and B. Droz (1970) Intraneuronal distribution of exogenous norepinephrine in the central nervous system of the rat. $J$. Cell Biol. 44: 385-399.

Furness, J. B., and M. Costa (1974) The adrenergic innervation of the gastrointestinal tract. Ergeb. Physiol. Biol. Chem. Exp. Pharmakol. 69: 1-51.

Furness, J. B., and M. Costa (1978) Distribution of intrinsic nerve cell bodies and axons which take up aromatic amines and their precursors in the small intestine of the guinea-pig. Cell Tissue Res. 188: 527543.

Furness, J. B., and M. Costa (1980) Types of nerves in the enteric nervous system. Neuroscience 5: 1-20.

Furness, J. B., M. Costa, and P. R. C. Howe (1980) Intrinsic aminehandling neurons in the intestine. In Histochemistry and Cell Biology of Autonomic Neurons, SIF Cells and Paraneurons, O. Eranko, S. Soinila, and H. Paivarintan, eds., pp. 367-372, Raven Press, New York.

Geffen, L. B., and B. Jarrott (1977) Cellular aspects of catecholaminergic neurons. In Handbook of Physiology. Vol. I: Nervous System, Cellular Biology of Neurons, Part I, J. M. Brookhart, V. B. Vernon, E. R. Kandel and S. R. Geiger, eds., pp. 521-572, American Physiological Society, Bethesda, MD.

Gershon, M. D. (1981) The enteric nervous system. Annu. Rev. Neurosci. 4: $227-272$.

Gershon, M. D., and E. B. Thompson (1973) The maturation of neuromuscular function in a multiply innervated structure. Development of the longitudinal smooth muscle of foetal mammalian gut and its cholinergic excitatory, adrenergic inhibitory, and non-adrenergic inhibitory innervation. J. Physiol. (Lond.) 234: 257-277.

Gershon, M. D., T. P. Rothman, G. N. Teitelman, T. Joh, and D. Reis (1982) Incomplete expression of a catecholaminergic phenotype in cells that transiently appear during development in the fetal rat gut. Soc. Neurosci. Abstr. 3: 189 .

Joh, T. H., C. Geghman, and D. J. Reis (1973) Immunochemical demonstration of increased accumulation of tyrosine hydroxylase protein in sympathetic ganglia and adrenal medulla elicited by reser- 
pine. Proc. Natl. Acad. Sci. U. S. A. 70: 2767-2771.

Jonakait, G. M., J. Wolff, P. Cochard, M. Goldstein, and I. B. Black (1979) Selective loss of noradrenergic phenotypic characters in neuroblasts of the rat embryo. Proc. Natl. Acad. Sci. U. S. A. 76: 46834686 .

Jonakait, G. M., K. A. Markey, M. Goldstein, and I. B. Black (1982) Transient expression of catecholaminergic traits in cranial nerve ganglia of the embryonic rat. Soc. Neurosci. Abstr. 8: 754.

Jonakait, G. M., K. A. Markey, M. Goldstein, and I. B. Black (1983) Not all transiently catecholaminergic cells of the rat embryo possess norepinephrine uptake. Soc. Neurosci. Abstr. 9: 305.

Kopriwa, B. M. (1975) A comparison of various procedures for fine grain development in electron microscopic radioautography. Histochemistry 44: 201-224.

Manber, L., and M. D. Gershon (1979) A reciprocal adrenergic-cholinergic axo-axonic synapse in the mammalian gut. Am. J. Physiol. 236: E738-745.

Rothman, T. P., and M. D. Gershon (1982) Phenotypic expression in developing murine enteric nervous system. J. Neurosci. 2: 381-393.

Rothman, T. P., L. L. Ross, and M. D. Gershon (1976) Separately developing axonal uptake of 5-hydroxytryptamine and norepinephrine in the fetal ileum of the rabbit. Brain Res. 115: 437-456.

Rothman, T. P., L. A. Specht, M. D. Gershon, T. H. Joh, G. Teitelman,
V. M. Pickel, and D. J. Reis (1980) Catecholamine biosynthetic enzymes are expressed in replicating cells of the peripheral but not the central nervous system. Proc. Natl. Acad. Sci. U. S. A. 77:62216225 .

Sternberger, L. A., P. H. Hardy, J. J. Cuculis, and H. G. Myer (1970) The unlabeled antibody enzyme method by immunohistochemistry: Preparation and properties of soluble antigen-antibody complex (horseradish peroxidase-antiperoxidase) and its use in identification of spirochetes. J. Histochem. Cytochem. 18: 315-333.

Teitelman, G., T. H. Joh, and D. J. Reis (1978) Transient expression of a noradrenergic phenotype in cells of the rat embryonic gut. Brain Res. 158: 229-234.

Teitelman, G., H. Baker, T. H. Joh, and D. J. Reis (1979) Appearance of catecholamine-synthesizing enzymes in rat embryo sympathetic nervous system: Possible role of tissue environment. Proc. Natl. Acad. Sci. U. S. A. 76: 509-513.

Teitelman, G., M. D. Gershon, T. P. Rothman, T. H. Joh, and D. Reis (1981a) Proliferation and distribution of cells that transiently express a catecholaminergic phenotype during development in mice and rats. Dev. Biol. 86: 348-355.

Teitelman, G., T. H. Joh, and D. J. Reis (1981b) Transformation of catecholaminergic precursors into glucagon (A) cells in mouse embryonic pancreas. Proc. Natl. Acad. Sci. U. S. A. 78: 5225-5229. 